\title{
The Mega Conglomerate of India- Success Story of Growth of Reliance Industries: A Case Study
}

\author{
Suchetha Vijayakumar ${ }^{1,2}$ \& Nethravathi P. S. ${ }^{3}$ \\ ${ }^{1}$ Research Scholar, College of Computer and Information Sciences, Srinivas University, \\ Mangalore, India \\ 2 Assistant Professor, AIMIT, St. Aloysius College (Autonomous), Mangalore, India \\ OrcidID : 0000-0001-8379-5651; Email : such_vijay@yahoo.com \\ ${ }^{3}$ Professor, College of Computer and Information Sciences, Srinivas University, Mangalore, \\ India \\ OrcidID : 0000-0001-5447-8673; Email : nethrakumar590@gmail.com
}

Area of the Paper: Information Technology.

Type of the Paper: Research Case Study.

Type of Review: Peer Reviewed as per $|\mathrm{C}| \mathrm{O}|\mathrm{P}| \mathrm{E} \mid$ guidance.

Indexed In: OpenAIRE.

DOI: http://doi.org/10.5281/zenodo.4940051

Google Scholar Citation: $\underline{\text { IJCSBE }}$

\section{How to Cite this Paper:}

VijayaKumar, Suchetha, \& Nethravathi, P. S., (2021). The Mega Conglomerate of IndiaSuccess Story of Growth of Reliance Industries: A Case Study. International Journal of Case Studies in Business, IT, and Education (IJCSBE), 5(1), 143-154. DOI: http://doi.org/10.5281/zenodo.4940051.

International Journal of Case Studies in Business, IT and Education (IJCSBE)

A Refereed International Journal of Srinivas University, India.

Crossref DOI : https://doi.org/10.47992/IJCSBE.2581.6942.0106

(C) With Authors.

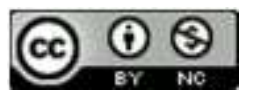

This work is licensed under a Creative Commons Attribution Non-Commercial 4.0 International License subject to proper citation to the publication source of the work.

Disclaimer: The scholarly papers as reviewed and published by the Srinivas Publications (S.P.), India are the views and opinions of their respective authors and are not the views or opinions of the S.P. The S.P. disclaims of any harm or loss caused due to the published content to any party. 


\title{
The Mega Conglomerate of India- Success Story of Growth of Reliance Industries: A Case study
}

\author{
Suchetha Vijayakumar ${ }^{1,2}$ \& Nethravathi P. S. ${ }^{3}$ \\ ${ }^{1}$ Research Scholar, College of Computer and Information Sciences, Srinivas University, \\ Mangalore, India \\ ${ }^{2}$ Assistant Professor, AIMIT, St. Aloysius College (Autonomous), Mangalore, India \\ OrcidID : 0000-0001-8379-5651; Email : such_vijay@yahoo.com \\ ${ }^{3}$ Professor, College of Computer and Information Sciences, Srinivas University, Mangalore, \\ India \\ OrcidID : 0000-0001-5447-8673; Email : nethrakumar590@gmail.com
}

\begin{abstract}
Background/Purpose: 'Growth' is the aim and goal of any company - be it a startup or a conglomerate. Of late, the retail industry is growing steadily, especially in the field of $e$ retailing. Reliance Industries which came into the Retail business in 2006 has seen rapid and consistent success in its growth. This success is due to an assortment of contributing factors worth discussing.
\end{abstract}

Objective: To observe the growth saga of Reliance Industries and review the contributing factors that helped this growth.

Design/Methodology/Approach: Analysis and presentation of information collected from various scholarly articles, web articles, and also using SWOC framework.

Findings/Result: Based on the study through various resources and also by analyzing the facts and figures, it is observed that sustaining in Retail market is a tough job which also requires many strategies and procedures to be amicably followed. Creativity and Innovation, Mergers and Acquisitions are some of the proven solutions for the same.

Research limitations/implications: The analysis and solutions mentioned in this paper are limited to Industries whose business and annual turnover and experience is as close to Reliance Industry.

Originality/Value: This paper focuses on various factors and scenarios that has made the growth of the Reliance Industry possible and taken it to the level of being labelled as mega Conglomerate.

Paper Type: A Research Case study paper on success story and contributing factors of Reliance Industry in becoming the mega Conglomerate of India.

Keywords: Reliance Industries, Business strategy, marketing strategy, jiomart, conglomerate, Porters five forces model, Corporate Social Responsibility

\section{INTRODUCTION :}

When we use the word 'Conglomerate', the first company that comes to our mind is Reliance Industries Limited (RIL). Mumbai, India is home to RIL's headquarters. Textiles, petrochemicals, fabrics, popular properties, retail, and telecommunications are among the companies that make up its corporate empire. After overtaking Indian Oil Corporation a few years ago, Reliance is now considered India's largest company in terms of revenue. In terms of market capitalization, Reliance Industries became the first Indian company to go over $\$ 100$ billion on October 18, 2007 [1]. The organization is ranked 106 on the Fortune Global 500 as of 2019 [1]. It is to be noted that the Ambani family still holds an approximate of $46 \%$ of the total shares, whereas $54 \%$ is held by public shareholders and corporate bodies, which is something commendable.

This case study has 12 sections. The first section gives a brief introduction about Reliance Industries. The second section includes the objectives of the case study. Section 3 specifies the methodology used to come up with the case study. Section 4 talks about the growth saga of reliance since its inception in the late 1950s. Section 5 includes a brief report on various brands and products of Reliance. The sixth 
section is about the business strategy of Reliance and also relates to Porter's Five Forces model. Section 7 consists of the Marketing Strategies of Reliance Industries. Section 8 throws light on the E-Retail wing of Reliance Industries in the name of JioMart. Section 9 tabulates the financial growth of the company with emphasis on Profit/Loss for the past 5 years. Section 10 contains relevant information about the Corporate Social Responsibility held by Reliance. In Section 11, a report of SWOC analysis is presented. Section 12 contains recommendations based on the challenges identified and also a conclusion of the case study.

\section{OBJECTIVES OF THE STUDY :}

- To study the growth saga of the most successful company in India - Reliance Industries.

- To study about the various brands, the products and services of Reliance Retail in particular.

- To analyze and know the business strategy of Reliance Retail.

- To study and analyze the e-business model of Reliance Retail

- To study the marketing strategy of Reliance Retail.

- To study the financial status of the Reliance Industry.

- To study the corporate social responsibility model of Reliance Retail and its effort on attaining environmental sustainability

- To conduct a SWOC analysis and suggest recommendations

\section{METHODOLOGY :}

The data required for this is collected through various secondary sources such as journals, published papers, archived newspaper articles and company websites of Reliance Retail and other ventures.

\section{ABOUT THE GROWTH SAGA OF RELIANCE :}

The growth of Reliance Industries did not happen overnight or within a specified time gap. It has been a step by step process starting from its inception in late 1950s till date [2]. The history of this step by step growth is summarized in the following table.

Table 1: Growth of Reliance Industries

\begin{tabular}{|c|c|}
\hline Year & Milestones \\
\hline $1958-1960$ & $\begin{array}{l}\text { The first business of Reliance Commercial Corporation was started by Dhirubhai } \\
\text { Ambani and Champaklal Damani. This was of trading spices [3]. }\end{array}$ \\
\hline 1965 & $\begin{array}{l}\text { Dhirubhai Ambani and Champaklal Damani put an end to their partnership. But } \\
\text { Ambani continued with the polyester business [3]. }\end{array}$ \\
\hline 1966 & In Maharashtra, 'Reliance Textiles Engineers Pvt. Ltd.’ was started. \\
\hline 1966 & A synthetic fabrics mill was established in the same year at Naroda in Gujarat [4]. \\
\hline 1973 & Reliance Industries Limited came into existence on May 8, 1973. \\
\hline 1975 & $\begin{array}{l}\text { During this year, the company ventured into textile business under the brand name } \\
\text { "Vimal" which became a famous brand in the coming years. }\end{array}$ \\
\hline 1977 & $\begin{array}{l}\text { The company brought in Initial public offering (IPO). Through this, Dhirubhai Ambani } \\
\text { saw to it that people of India get introduced to equity cult which was a new model of } \\
\text { business in the form of public shareholding. [5]. }\end{array}$ \\
\hline 1979 & Sidhpur Mills was merged with Reliance Industries [6]. \\
\hline 1980 & A Yarn Plant specialized in Polyester filament was set up in Patalganga, Raigad [4]. \\
\hline 1985 & Reliance Textiles Industries Ltd. got renamed to Reliance Industries Ltd (RIL) [4]. \\
\hline 1985 to 1992 & $\begin{array}{l}\text { RIL increased its production of polyester yarn to more than } 1,45,000 \text { tonnes per annum } \\
\text { [4]. }\end{array}$ \\
\hline 1991 to 1992 & The Hazira petrochemical plant was officially authorized [7]. \\
\hline 1993 & $\begin{array}{l}\text { Though Reliance Petroleum and a global depository issue, Reliance approached the } \\
\text { capital markets of other countries for funds. }\end{array}$ \\
\hline 1996 & $\begin{array}{l}\text { International credit rating agencies gave rating to the Company after which it became } \\
\text { the first ever private sector company to achieve this fete [8]. }\end{array}$ \\
\hline $1995-96$ & $\begin{array}{l}\text { Reliance Telecom Private Limited was flagged off as the company entered into a joint } \\
\text { venture along with NYNEX, USA [7]. }\end{array}$ \\
\hline $1998-99$ & Under the brand name of Reliance Gas, $15 \mathrm{~kg}$ LPG cylinders were introduced in the \\
\hline
\end{tabular}




\begin{tabular}{|l|l|}
\hline & market [7]. \\
\hline $1998-2000$ & The largest refinery in the world at Jamnagar, Gujarat was constructed [7]. \\
\hline $2001-02$ & Reliance Industries absorbed Reliance Petroleum [5]. \\
\hline 2002 & $\begin{array}{l}\text { The first ever gas discovery took place at the Krishna Godavari basin which also } \\
\text { happened to be the first ever discovery by an Indian private sector company [5]. }\end{array}$ \\
\hline $2002-03$ & $\begin{array}{l}\text { RIL had the fame of buying primary/majority stake in Indian Petrochemicals } \\
\text { Corporation Ltd. (IPCL) from the Government of India [9]. }\end{array}$ \\
\hline 2008 & $\begin{array}{l}\text { IPCL got merged with RIL and so IPCL's Nagothane and Dahej manufacturing units } \\
\text { came under RIL [10]. }\end{array}$ \\
\hline 2006 & $\begin{array}{l}\text { 'Reliance Retail' came into the market and this marked its entry into e retail market in } \\
\text { India [11]. }\end{array}$ \\
\hline 2009 & $\begin{array}{l}\text { Reliance Industries reached to its peak by issuing 1 share to every share owned (1:1) } \\
\text { to its shareholders in November 2009. }\end{array}$ \\
\hline 2010 & $\begin{array}{l}\text { Reliance placed its footstep into the broadband services market by acquiring Infotel } \\
\text { Broadband Services Limited with 4G spectrum through an auction held by the } \\
\text { Government of India [12] [13]. }\end{array}$ \\
$\begin{array}{l}\text { This great year saw a partnership between Reliance and Bharath Petroleum (BP) in the } \\
\text { field of oil and gas business. BP took a 30\% stake in a total of 23 oil and gas production } \\
\text { sharing contracts which were operated by Reliance in India for \$7.2 billion [18]. } \\
\text { Reliance also signed a 50:50 joint venture with BP for sourcing and marketing of gas } \\
\text { in India [14]. }\end{array}$ \\
\hline $\begin{array}{l}\text { Russian Company 'Sibur' and Reliance Industries set up a joint venture for setting up } \\
\text { a Butyl rubber plant in Jamnagar, Gujarat which was to be operational by 2018 [15]. }\end{array}$ \\
\hline 2017 & $\begin{array}{l}\text { Reliance added Fynd mainly for its consumer businesses and mobile phone services in } \\
\text { the e-commerce space [16] [17]. }\end{array}$ \\
\hline 2019 & $\begin{array}{l}\text { Acquisition of Future Group for Rs 24,713 Cr (Process not fully completed due to } \\
\text { intervention of Amazon) [18]. }\end{array}$ \\
\hline 2020 &
\end{tabular}

\section{VARIOUS BRANDS OF RELIANCE RETAIL AND THEIR PRODUCTS:}

Reliance Retail operates chain of various business outlets across the country [19] . Each of these brands have their own priorities and line of business. The following table summarizes some of the many brands of Reliance retail

Table 2: Various brands and products of Reliance Retail

\begin{tabular}{|c|c|c|}
\hline Brand & Description and Products & Website / e-shopping site \\
\hline Reliance Fresh & $\begin{array}{l}\text { Largest chain of store for Fresh } \\
\text { Vegetables, fruits and dairy } \\
\text { products }\end{array}$ & - \\
\hline Reliance Smart & $\begin{array}{l}\text { Supermarket offering } \\
\text { everything including fresh } \\
\text { produce, bakery, dairy } \\
\text { products, home appliances and } \\
\text { general merchandise under one } \\
\text { roof }\end{array}$ & https://www.reliancesmart.in \\
\hline Smart Point & $\begin{array}{l}\text { A convenience store to order } \\
\text { goods online and pick them up } \\
\text { from local Smart Point }\end{array}$ & http://reliancesmartpoint.com/ \\
\hline Jio Mart & Online Grocery Store & https://www.jiomart.com/ \\
\hline Reliance digital & $\begin{array}{l}\text { Largest consumer retail chain } \\
\text { of electronic items and goods }\end{array}$ & https://www.reliancedigital.in/ \\
\hline Trends & $\begin{array}{l}\text { Largest fashion shopping spot } \\
\text { for men, women and kids }\end{array}$ & https://www.trends.ajio.com/ \\
\hline Trends footwear & Largest retail chain of footwear & - \\
\hline Reliance jewels & $\begin{array}{ll}\begin{array}{l}\text { Leading jewellery specialty } \\
\text { retail chain }\end{array} & \\
\end{array}$ & https://www.reliancejewels.com/ \\
\hline
\end{tabular}




\begin{tabular}{|l|l|l|}
\hline Ajio.com & Curated online fashion store & https://www.ajio.com/ \\
\hline
\end{tabular}

\section{BUSINESS STRATEGY ADOPTED BY RELIANCE RETAIL:}

Porter's Five Forces Model is simple yet a powerful tool to assess and get to know about the competitive factors which affect the environment in a business and also to know about how to achieve and make profits.

According to Porter, there are five forces which takes an Industry to the topmost position [20]. These forces are:

1. Fear of fresh entrants to the market

2. Suppliers and their power to bargain

3. Buyers and their power to bargain

4. Fear of like/substitute Products

5. Rivalry from Competitive products

Reliance Retail closely comply to Porter's Five Forces Model which is as discussed below:

(i) Fear of fresh entrants to the market: According to Porter, new companies and retail industries in the current scenario can introduce new products and can drastically reduce product prices and also the profit of the existing industry or firm. Any Retail sector is exposed to high threats of new entrants due to low setup cost and need for infrastructure. But Reliance Retail is able to withstand the threat of new entrants by making themselves unique among all other retail companies by providing a very good customer support and high quality products and a variety of products. The price of all retail products is kept reasonably nominal with various discount offers from time to time, which is not possible for any new entrants. Reliance is already an established brand which acts as a barrier for new entrants into the market.

(ii)Suppliers and their power to bargain: This depends on the concentration of suppliers, that is how many such suppliers exist and the amount of work. The other factors which enhance Supplier's strength are the total count of suppliers for every product and also the unique feature of the products/service [20]. Reliance has a very good potential supplier base for each of the products that they sell and also have their own brand of products, which makes it beneficial in terms of uniqueness of products and also helps in keeping other suppliers under control so that they don't increase the prices and terms and conditions.

(iii) Buyers and their power to bargain: Assessing the power of buyers to bargain can be done by asking a simple question such as 'how easy is it for buyers to bring the prices down of your products?'. This is related to a number of factors, such as how important every buyer is to your business, how important your product is to the buyers, how often the buyers usually switch from your product to that of the competitors or circulation of similar products in the market. Sometimes the powerful buyers may rule you by their dictating terms [20]. In the case of Reliance retail, this is minimal. The reason being the low price, good quality and, of course, customer loyalty. Over time the company's popularity increases with the increase in the number of customers. This is so true with Reliance retail.

(iv) Fear of like/substitute Products: This is one of the important driving forces to bring down business. This refers to the way your customer finds a substitute for what you have been doing or offering. A substitution in this way can always weaken the position and also pose a threat to the profitability of the business. Definitely, there has been a great deal of threat from substitute products for Reliance Industries. Especially from the products that are manufactured in China, the Philippines and Thailand. This has been happening for quite some time now and has posed a great threat to all companies and industries. But Reliance retail has been able to cope up with the threat of substitutes in a unique way by offering quality products unlike the ones that are manufactured in other countries and also by pricing them aptly and giving to the customers.

(v) Rivalry from Competitive products: Competitive Rivalry means how many competitors you have and what the capability of your competitors is. If business has a large number of competitors offering equally attractive and good products and services, then that business will have little or no power at that point of time. Suppliers, buyers and competitors will not continue their business with you if they come to know that there is no benefit from you. Also, if nobody is able to offer the products at the 
price that you have been giving at, it is understood that you have great strength in the business. To be precise, rivalry from competitors is said to be high when there are not just a few establishments that sell a product or service at the same price which you have been offering. Reliance retail has been coping with Competitive Rivalry really well. Of recent it has acquired many such businesses such as Fynd, Future group, etc.

Expansion of business and penetration into business can be considered as the two major factors for success of an industry. Reliance retail has been doing this effectively, though penetration into the market is not one of the factors of Porter's five-forces model. But expansion can be achieved by increasing the number of retail outlets and also by more acquisition of related companies.

\section{MARKETING STRATEGY OF RELIANCE RETAIL:}

'Reliance' houses a variety of products ranging from a small safety pin to something as costly as gold and platinum. In order to cater to a broader segment of people, RIL employs a clever mix of demographic, geographic, and psychographic segmentation, as well as variables like occupation, gender, age, income level, behaviour, and area [21] [22].

There are several other marketing strategies of Reliance Retail such as innovation in product/service, investment in marketing, experiences of customers etc. which have added to its considerable growth. The benefit of applying these marketing strategies and 4P's that it helps in achieving the business goals \& objectives [23].

Popular marketing strategies [24] of Reliance retail include:

- Loyalty Membership card: A loyalty membership card id issued to every customer in which points get accumulated on every purchase done. These points can be redeemed in adjustment of future purchases.

- Advertising and Promotion: The amount that Reliance spends on promotional activity and advertising is proven to be very less when compared to other companies. It is said to be following all the three types of advertising and marketing strategies such as 'Above the Line strategy', 'Below the Line strategy' and 'Through the Line Strategy'.

- One stop shop: Most of the Reliance Retail outlets including some e-shopping sites provide single stop shopping experience for variety of products. This makes it easy and convenient for the customers instead of moving to different places for different items.

- Discounts and Positioning: The main marketing strategy followed by Reliance Retail is the various discounts that they offer on products. For ex: Buy 2 get 1 free or $50 \%$ off on the second item purchased etc. This works out for the company because of the fact that the items are purchased in bulk and few of them are given for free for the amount of purchase that is being done. Also, the positioning of the various items and products in the retail outlets also adds on to the marketing strategy. The products with highest discount offers are positioned at the entrance and other prominent places.

- The Ambience of retail outlets: This adds on to all the marketing strategies specified above. The appearance, the ambience and a spacious floor space for shopping is another feather in the cap when it comes to marketing strategy of Reliance Retail

\section{JIOMART - THE E-RETAIL PLATFORM OF RELIANCE :}

In India, retailing is growing more significant, and organised retailing is expected to grow at a rapid pace [25]. The very latest addition to Reliance Industries is the Digital grocery store namely JioMart which uses the customer base of Jio and Reliance Retail. JioMart can be used as an App or can be directly accessed through URL. Of late, Reliance got Rs. 43,574 crores from Facebook in return of 9.99\% equity stake of Jio so as to set a new beginning for 'kirana store' owners to enable their connection with customers. [26]. In India, presently JioMart operates in more than 200 towns. Though JioMart is an establishment of a long term dream of Reliance Industries, it had to compete with the name and fame created to by big giants like Amazon, Big basket, Udaan and other digital grocery stores. Through 
JioMart, Reliance Industries moved to O2O (Online to Offline) business which was actually a model built by Alibaba group. Under $\mathrm{O} 2 \mathrm{O}$, the customer finds the product online and buys it through an offline channel [27]. An extension of $\mathrm{O} 2 \mathrm{O}$ business model nowadays is to order and pay for the items online and collect them at a physical location offline. JioMart's business model also works on $\mathrm{O} 2 \mathrm{O}$ model where the customer orders are placed through online mode and products are delivered from the local stores [28].

\section{JioMart- Features:}

The following special features of JioMart has been making it more reliable and famous among customers:

- No Cost door step delivery: Jio Mart offers free home delivery of its orders to the customers.

- No minimum value: Jio Mart is offering the $\mathrm{O} 2 \mathrm{O}$ services to its customers without any condition on the total amount of products ordered.

- Quick and fast Delivery: The time taken to fulfil/deliver the orders is very less due to the fact that they are delivered through the local Kirana stores.

- Discounts and Offers: JioMart offers heavy discount on every product to an extent of $50 \%$.

With all the above features, JioMart is all set to conquer the e-retail setup in India.

\section{FINANCIAL GROWTH OF RELIANCE INDUSTRIES :}

Financial analysis is the phenomenon of determining the performance and suitability of and feasibility of projects, budgets, and other financial operations. The following table shows the Financial growth of Reliance for the past years from 2016-2020 [29].

Table 3: Financial statements of Reliance Industries:

\begin{tabular}{|c|c|c|c|c|c|}
\hline \multicolumn{6}{|l|}{ Rs (in Crores) } \\
\hline & Mar'20 & Mar'19 & Mar'18 & Mar'17 & Mar'16 \\
\hline \multicolumn{6}{|l|}{ INCOME } \\
\hline Net Sales Turnover & 335978 & 371616 & 290042 & 242025 & 233158 \\
\hline Other Income & 14541 & 8822 & 8220 & 8709 & 7821 \\
\hline Total Income & 350519 & 380438 & 298262 & 250734 & 240979 \\
\hline \multicolumn{6}{|l|}{ EXPENSES } \\
\hline TOTAL EXPENSES & 284125 & 312762 & 238301 & 198769 & 193811 \\
\hline Operating Profit & 51853 & 58854 & 51741 & 43256 & 39347 \\
\hline EBITDA & 66394 & 67676 & 59961 & 51965 & 47168 \\
\hline Depreciation & 9728 & 10558 & 9580 & 8465 & 8590 \\
\hline EBIT & 56666 & 57118 & 50381 & 43500 & 38578 \\
\hline Interest & 12105 & 9751 & 4656 & 2723 & 2562 \\
\hline EBT & 44561 & 47367 & 45725 & 40777 & 36016 \\
\hline Taxes & 9413 & 12204 & 12113 & 9352 & 8632 \\
\hline Profit and Loss for the Year & 35148 & 35163 & 33612 & 31425 & 27384 \\
\hline
\end{tabular}




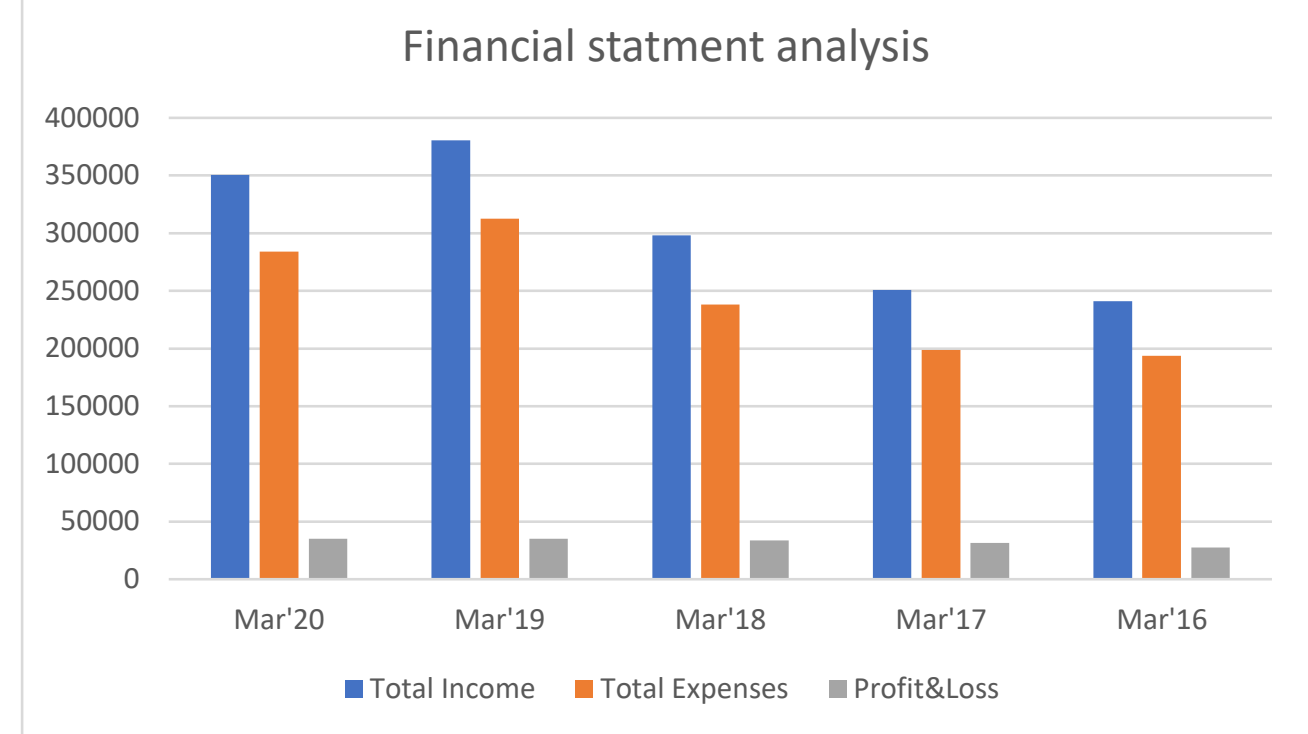

Fig 1: Chart - To show Total Income, Total Expenses and Profit \& Loss

The above chart clearly reflects the consistency in Reliance Industry with respect to Profit/Loss.

\section{CORPORATE SOCIAL RESPONSIBILITY AND ATTAINING ENVIRONMENTAL SUSTAINABILITY :}

Corporate social responsibility (CSR) of an organization helps a company to be socially accountable by persuing social objectives [30]. CSR is a is a self-regulated and self-controlled business model. The main objective of CSR is to do good to the society, take part in charitable and good causes, and return constructive social value. Almost all organizations and companies are these days taking up CSR to make a difference to the society and build a positive brand about their company [31].

Smt Nita M Ambani, the Founder and chairperson of Reliance Foundation is the key mentor of CSR initiatives of RIL. Through her efforts, CSR initiatives of RIL has been able to uplift and help 3.6 crore people across 40000 villages and other locations in India [32].

Over the years, Reliance Foundation has got itself involved in many CSR programmes which has benefited millions of Indians. Several activities like Rural development, Health and Sanitation, Development of Sports, Disaster Recovery and Response are being conducted. Major National Campaigns like 'Swacchhatha hi seva' and 'Jal Shakthi Abhiyan' have been actively supported and encouraged by CSR initiatives of RIL. Not only this, it is also one among the first companies to come forward to help whenever there is any National emergency or Natural disasters. Recently RIL's helping hand towards COVID-19 effected community has earned accolades and praises [32].

Reliance CSR initiatives are based on the following: [33]

(a) Direct involvement and commitment with the company

(b) Entering into partnerships and tie ups

(c) Investing on technology

Reliance CSR has successfully created almost 600 Village Associations and more than 3000 leaders who are given in charge of development of their own villages. Farmers are encouraged to form Farmer Producer Companies (FPCs), which are owned and run by the farmers themselves, and which bring them together for economies of scale and better market prices [33]. It has also set up digital platforms to help in information dissemination. In the field of education too, Reliance CSR is offering continued support and encouragement through scholarships and freeships. Dhirubhai Ambani Scholarship Programme (DAS) is instantiated to promote the mission and vision of Sri Dhirubhai Ambani. Reliance Foundation Schools are setup through which quality education is being offered to students right from kindergarten to class 12. In the area of Healthcare also, Reliance CSR has a great role to play. It has set up Sir H N Reliance Foundation Hospital and Research Centre in Mumbai which is of great help to as many as 1.80 lakh families. A Project titled 'ASMAN' is a blended partnership between many giants such as Reliance Foundation, Tata Trusts, MSD for Mothers, Bill and Melinda Gates Foundation and United States Agency for International Development. The key goal of 'ASMAN' is to improve the quality of public health services in order to enhance the healthcare system for mothers and newborns 
[33]. In collaboration with the National Association for the Blind, Arvind Eye Hospital, and Shankar Eye Foundation, the Reliance Foundation Drishti programme has been assisting underprivileged people in undergoing various surgeries. Not only these Reliance is the first private enterprise to join hands in rescue operations and setting up refugee camps for disaster response.

Table 4: CSR expenditure of Reliance Industries for the last 6 years: [32]

\begin{tabular}{|l|c|}
\hline FY & $\begin{array}{c}\text { CSR Expenditure } \\
\text { (Rs. Crore) }\end{array}$ \\
\hline $2014-15$ & 762 \\
\hline $2015-16$ & 659 \\
\hline $2016-17$ & 674 \\
\hline $2017-18$ & 771 \\
\hline $2018-19$ & 904 \\
\hline $2019-20$ & 1022 \\
\hline
\end{tabular}

Since its inception, the Reliance Foundation has touched the lives of many millions of Indians through the above CSR projects in India. All the activities and projects mentioned so far are aimed at bringing about transformative change in the country. This is the goal and aim of Reliance foundation. The socially beneficial projects have reached every corner of India, and Reliance plans to step up its efforts, especially through digital technology, to reach even more people across the country.

\section{SWOC ANALYSIS :}

SWOC Analysis is used to determine the various internal and external factors that will directly affect their operations or business [34] [35]. The following Strengths, Weakness, Opportunities and Challenges are identified for Reliance Industries [36-37].

\section{Strengths:}

- Having a very strong Market position: Reliance has a very strong market position including being one among Fortune Global 500 and first ever Indian company to being added there.

- Strong financial position: The strong financial position of Reliance sees to that it can expand its business to various horizons.

- Brand image: 'Reliance' by itself is a well-known brand. Therefore, it does not require a secondary brand to promote it.

- Mind blowing infrastructure: Jio4G talks about the infrastructure capabilities of Reliance where nationwide 4G services are being offered.

- Backward integration of business: It shows a great improvement in value chain by procuring items from farmers and selling it to customers.

\section{Weakness:}

- Decline in production: This is especially seen in gas and petroleum sector due to natural and operational challenges.

- Decline in global expansion: Global expansion of the business is greatly affected due to some divesting and relinquishing activities.

- High investment in training Employees: As business expands, new employees are recruited and trained. If attrition rate is high, it is a huge loss.

\section{Opportunities:}

- New investments: Reliance should go far with new investments globally and become world leader

- Acquisition of global market: With its vast business which is wide spread into various sectors, Reliance should definitely make into global market in the future.

- Focus on potential business and customers: Though the target is global market, high level of focus is required on potential business and customers.

\section{Challenges:}


- Legal problems/scams/controversies: Reliance always has faced problems in one way or the other which is the major challenge for its continuous growth. The good examples have been Demerger of Reliance Industries, SEBI's show cause notice to Reliance regarding insider training, Amazon's objection in buying Future Group and many more.

- Tough competition in the global market: Though a brand on its own with all the required infrastructure and capabilities, there is always a tough competition from like retail stores that come up every now and then. Ex: D-Mart.

- Stringent Government policies: The regulating Government policies are always a hindrance and challenge for Reliance.

- Increase in inflation: Increasing Inflation rates are a concern when it comes to financial growth of the company.

\section{RECOMMENDATIONS AND CONCLUSION :}

Based on the challenges identified in the SWOC analysis, the following recommendations can be made. Though legal problems are quite common in the empire of business of type that Reliance is into, it is better to tackle such issues wisely, as the brand image will definitely be affected. Competition in the field of e-retailing sector is also increasing day by day. Hence more innovation and creativity with respect to e-retailing has to be developed. More of acquisition is required to sustain the business.

To conclude, Reliance is one of India's most profitable firms, as well as the country's largest publicly traded firm by market capitalization and the country's all-time largest company by sales [38]. As per the statistics of Income Tax Department, among India's private sector companies, Reliance is the largest income tax payer. Its commitment to "bettering the lives" of people is more evident in its pursuit of making a difference on social socio-economic issues in India as mentioned in this paper.

\section{REFERENCES}

[1] How Reliance Industries Limited Became India's Biggest Company [Reliance Industries Case Study] (2021). Retrieved from https://startuptalky.com/reliance-industries-case-study/ on $13 / 03 / 2021$.

[2] Reliance Industries. Retrieved from https://en.wikipedia.org/wiki/Reliance_Industries on $13 / 3 / 2021$.

[3] Farouk Luqman (November 2012). Ambani: From a gas station attendant to Reliance owner. Retrieved from https://www.arabnews.com/ambani-gas-station-attendant-reliance-owner on $13 / 03 / 2021$.

[4] Company History - Reliance Industries Ltd. Retrieved from https://web.archive.org/web/20130928201223/http://economictimes.indiatimes.com/relianceindustries-ltd/infocompanyhistory/companyid-13215.cms on 14/03/2021.

[5] Major milestones.

Retrieved from https://web.archive.org/web/20130817071250/http://www.ril.com/html/aboutus/major_milestone s.html on 13/03/2021.

[6] Company history - $\quad$ Reliance Industries. Retrieved from https://web.archive.org/web/20130812123146/http://www.moneycontrol.com/companyfacts/relianceindustries/history/RI on 14/03/2021 On 14/03/2021.

[7] Reliance Industries Ltd. Retrieved from https://web.archive.org/web/20140110093244/http://www.hdfcsec.com/Market/Information.aspx ?CoCode $=476 \&$ RptType=History on 13/03/2020.

[8] Reliance Industries: Milestones of an Oil giant (October 2012). Retrieved from https://www.ndtv.com/photos/business/reliance-industries-milestones-of-an-oil-giant-13970 on $13 / 03 / 2021$.

[9] Raghuvir Srinivasan (2002). Reliance makes it big with IPCL. Retrieved from https://web.archive.org/web/20120414005325/http://www.thehindubusinessline.in/2002/05/20/st ories/2002052000790500.htm on 13/03/2021. 
[10] BS Reporter (March 2007). IPCL set to merge with Reliance Industries. Retrieved from https://web.archive.org/web/20140110135049/http://www.business-standard.com/article/ companies/ipcl-set-to-merge-with-reliance-industries-107030801104_1.html on 13/03/2021.

[11] Retail: Growth Engine For RIL. (2021). Information Retrieved from https://web.archive.org/web/20141208025311/http://www.btvin.com/videos/watch/7595/retail:growth-engine-for-ril on 14/03/2021.

[12] Amol Sharma and Eric Bellman (June 2010). Reliance Bets Big on 4G. Retrieved from https://web.archive.org/web/20150318033739/http://www.wsj.com/articles/SB100014240527487 03509404575300313733929690 on $14 / 03 / 2021$.

[13] Special Correspondent (June 2010). Reliance Industries to acquire Infotel Broadband. Retrieved from

https://web.archive.org/web/20140110090700/http://www.thehindu.com/business/companies/reli ance-industries-to-acquire-infotel-broadband/article452893.ece on 14/03/2021.

[14] Bureau, E T (August 2011), Reliance Industries, BP complete \$7.2-billion deal. Retrieved from https://web.archive.org/web/20130908113359/http://articles.economictimes.indiatimes.com/2011 -08-31/news/29949268_1_positions-in-significant-hydrocarbon-bob-dudley-bp on 14/03/2021.

[15] Jan 2017, RIL, Russia's Sibur join hands for Jamnagar butyl rubber unit. Retrieved from https://economictimes.indiatimes.com/industry/indl-goods/svs/petrochem/ril-russias-sibur-joinhands-for-jamnagar-butyl-rubber-unit/articleshow/56644960.cms?from=mdr on 16/03/2021.

[16] Bloomberg (August 2019). Reliance to buy Google-backed tech start-up Shopsense Retail. Retrieved from https://www.thehindubusinessline.com/info-tech/reliance-to-buy-google-backedtech-start-up-shopsense-retail/article28821784.ece on 15/03/2021.

[17] August 2019, Disclosure under Regulation 30 of SEBI. Retrieved from https://www.ril.com/DownloadFiles/CorporateAnnouncements/Reg30_Shopsense.pdf on $16 / 03 / 2021$

[18] PTI (August 2020). Ambani's Reliance buys stake in Future Group for Rs 24,713 cr. Retrieved from https://timesofindia.indiatimes.com/business/india-business/ambanis-reliance-buys-stakein-future-group-for-rs-24713-cr/articleshow/77825421.cms on 16/03/2021.

[19] Website of Reliance Retail. Retrieved from https://relianceretail.com/ on 24/02/2021.

[20] Dakhole Abhishek, Mane Dattatry (2017). A Research Paper on Assessment of Porters Five Competitive Forces in Indain IT Sector. International Journal of Advance Research, Ideas and Innovations in Technology, 3(3), 33-36.

[21] Hitesh Bhasin (May 2019). Marketing Strategy of Reliance Industries Limited. Retrieved from https://www.marketing91.com/marketing-strategy-of-reliance-industries-limited/ on 14/03/2021.

[22] Shubham Parsoya, Asif Perwej (2020). Analysis of the Marketing Strategies of Reliance Industries (Petroleum \& Oil Company) In Enhancing Its Petroleum Business \& Establishing as a global level Petroleum Company. IJSREM, 4(12), 1-4.

[23] MBA Skool Team (April 2020). Reliance Retail Marketing Mix (4Ps) Strategy. Retrieved from https://www.mbaskool.com/marketing-mix/services/17785-reliance-retail.html on 20/03/2021.

[24] Shenoy, S. (2016). A Study on Marketing Strategies Adopted by Reliance to Push their Sales in their Retail Mall Sahakari Bhandar. Andrean Research Journal, 6(1), 27-38.

[25] Rathore, S. S., \& Rathore, P. (2019). Retail management (a case study on reliance industries). International Journal of Research in Social Sciences, 9(10), 34-44.

[26] Srikant Kapoor (2020). Case Study: JioMart - A New Giant in Digital Grocery Ecosystem. International Journal of Science and Research (IJSR), 9(10), 1134 - 1136.

[27] Gupta, P., \& Sharma, N. (2020). A Review of Changing Contours of Retail during COVID 19 pandemic in a Post-Digital World. International Journal of Psychosocial Rehabilitation, 24(05), 
8770-8780.

[28] JioMart Team (July 2020). JioMart Business Model: How Reliance's Jio Mart Works \& Makes Money? Retrieved from https://jiomartshop.com/jiomart-business-model/, on 21/03/2021.

[29] Reliance Industry Yearly Results, Financial summary. Retrieved from $\mathrm{https} / / /$ economictimes.indiatimes.com/reliance-industries-ltd/yearly/companyid-13215.cms on $21 / 03 / 2021$

[30] Amaladoss, M. X., \& Manohar, H. L. (2013). Communicating corporate social responsibility-A case of CSR communication in emerging economies. Corporate Social Responsibility and Environmental Management, 20(2), 65-80.

[31] Dr. P. N. Shende, (2016). Study Of Corporate Social Responsibility (Csr) Vision and Policy (with special reference to Reliance Industries Ltd.). International Research Journal of Multidisciplinary Studies, 2(6), 1-6.

[32] Rusen Kumar (July 2020). Corporate Social Responsibility (CSR): Reliance Industries spends Rs. 1022 Cr on Social Development. Retrieved from https://indiacsr.in/corporate-social-responsibilitycsr-reliance-industries-spends-rs-1022-cr-on-social-development/ on 23/03/2021.

[33] Hency Thacker, T. (April 2021), The Definitive CSR Report of Reliance Industries Ltd. Retrieved from https://thecsrjournal.in/csr-report-reliance-industries-limited/, on 23/04/2021.

[34] Aithal, P. S. (2017). Company Analysis-The Beginning Step for Scholarly Research. International Journal of Case Studies in Business, IT and Education (IJCSBE), 1(1), 1-18.

[35] Aithal, P. S. (2017). An effective method of developing business case studies based on company analysis. International Journal of Engineering Research and Modern Education (IJERME), 2(1), $16-27$.

[36] Holla, Raghavendra, (2017). A Study on SWOC Analysis of Reliance Jio. International Journal of Engineering Research and Modern Education (IJERME), 2(1), 42-47.

[37] Aithal, P. S., \& Kumar, P. M. (2015). Applying SWOC Analysis to an Institution of Higher Education. International Journal of Management, IT and Engineering, 5(7), 231-247.

[38] Top 100 Companies by Market. Retrieved from https://www.bseindia.com/markets/equity/EQReports/TopMarketCapitalization.aspx on $24 / 03 / 2021$. 